\title{
In vitro transcription of HIV-1 RNA for standard RNA
}

\author{
Andi Yasmon, ${ }^{1}$ Budiman Bela, ${ }^{1}$ Fera Ibrahim, ${ }^{1}$ Elisna Syahruddin ${ }^{2}$ \\ ${ }^{1}$ Department of Microbiology, Faculty of Medicine, Universitas Indonesia, Jakarta, Indonesia \\ ${ }^{2}$ Department of Pulmonology and Respiratory Medicine, Faculty of Medicine Universitas Indonesia/Persahabatan General \\ Hospital, Jakarta, Indonesia
}

\begin{abstract}
Abstrak
Latar belakang: Uji kuantitatif merupakan uji yang penting dalam memonitor penatalaksanaan pasien yang terinfeksi HIV-1 atau yang menderita AIDS. Tahap penting dalam pengembangan uji tersebut adalah tersedianya RNA HIV-1 standar. Oleh karena itu, dalam penelitian ini transkripsi RNA HIV-1 dioptimasi untuk menghasilkan RNA HIV-1 standar.

Metode: Menggunakan teknik PCR, DNA HIV-1 diamplifikasi dari pNL43 menggunakan sepasang primer yang spesifik pada daerah yang dikonservasi dari gen Gag HIV-1. Produk PCR kemudian diklon ke dalam pBluescript II KS. Plasmid rekombinan dipotong menggunakan enzim restriksi EcoRI. Plasmid yang telah dipotong kemudian digunakan sebagai cetakan untuk reaksi transkripsi RNA. Reaksi RT-PCR dan PCR dilakukan secara bersamaan untuk mengkonfirmasi adanya fragmen RNA yang telah ditranskripsi.
\end{abstract}

Hasil: Fragmen DNA sebesar 115 bp dari daerah gen Gag HIV-1 telah berhasil diklon ke dalam pBluescript II SK dengan orientasi yang benar. Reaksi transkripsi RNA juga berhasil dilakukan. Hasil transkripsi RNA telah dikonfirmasi dan menunjukkan hasil transkripsi RNA yang benar.

Kesimpulan: Dalam studi ini telah berhasil dilakukan konstruksi plasmid rekombinan yang mengandung daerah yang dikonservasi dari gen Gag HIV-1, dan RNA HIV-1 juga berhasil ditranskripsi secara in vitro. (Med J Indones. 2011; 20:185-9)

\begin{abstract}
Background: The quantitative assays are important tests in the management of patients with HIV-1/AIDS. The important step in developing the assay is the availability of the standard HIV-1 RNA. For this purpose, we optimized in vitro HIV-1 RNA transcription to produce the standard HIV-1 RNA.

Methods: The HIV-1 DNA was amplified from pNL43 by PCR using a primer pair that was specific for conserved region of HIV-1 Gag gene. The PCR product was further cloned into pBluescript II KS. The recombinant plasmid was restricted with EcoRI enzyme. Then, the linearized plasmid was used as template for RNA transcription. RT-PCR and PCR were performed simultaneously for confirmation of synthesized RNA fragment.

Results: A 115 bp DNA of HIV-1 Gag gene has been cloned into pBluescript II SK with the exact true orientation. The reaction of the RNA transcription was also successfully performed. The RNA transcripts have been confirmed and showed the accuracy of the transcripts.

Conclusion: we successfuly constructed the recombinant plasmid containing a conserved region of HIV-1 Gag gene, and the HIV-1 RNA has been transcribed in vitro as well. (Med J Indones. 2011; 20:185-9)
\end{abstract}

Key words: HIV-1/AIDS, Quantitative assay, RNA transcription

Reverse transcription-polymerase chain reaction (RTPCR) is a known technique to transcript RNA to cDNA (complementary DNA), and then cDNA was amplified by PCR. The advantage of this technique is the ability to detect HIV genome RNA in the early phase of infection when HIV-1 specific antibody is not yet produced by a newly HIV-1 infected person, or in the late phase in which antibody is unable to be detected. ${ }^{1}$

Recently, we reported a qualitative RT-PCR assay which was potential to be used as an alternative test for detection of HIV-1 infection. ${ }^{2}$ However, the assay could not be applied for quantification of viral genome number in certain specimens. The quantitative assay is important to monitor the efficacy of antiviral therapy of AIDS disease, preventing HIV-1 transmission from mother to infant, predicting the rate of disease progression and the time to development of AIDS or death. ${ }^{3-5}$
To develop a valid quantitative RT-PCR, one should have a standard RNA to establish a curve of several viral RNA concentrations. The curve will be used to determine the number of viral genome copies (viral load). For that purpose, in this study we performed and optimized in vitro transcription of the HIV-1 RNA for standard RNA that can be used in the quantitative RT-PCR in the future.

\section{METHODS}

\section{HIV-1 strain}

The HIV-1 DNA was amplified from PNL43 plasmid (the plasmid containing whole genome of HIV-1 subtype B).

\section{Recombinant DNA techniques}

Restriction endonucleases were purchased from New England Biolabs and were used following manu- 
facturer's specifications. The primers were synthesized by Gene Works-Australia. Other recombinant DNA methods were performed according to Ausubel et al. ${ }^{6}$

\section{Recombinant plasmid construction}

A 115-bp DNA of HIV-1 Gag fragment was amplified by using HI853F (5'- CAG CAT TAT CAG AAG GAG CCA C-3)' and HI967R (5'-TCT GCA GCT TCC TCA TTG ATG G-3') primers. The PCR was performed in $100 \mu$ L of reaction mixture with following compositions: 1x PCR Buffer, $2.5 \mathrm{mM} \mathrm{MgCl}_{2}$, 1x Q solution, $200 \mu \mathrm{M}$ of dNTP mix; $0.4 \mu \mathrm{M}$ of each HI853F and HI967R primer; $2.5 \mathrm{U}$ of HotStar Taq DNA polymerase, $10 \mathrm{ng}$ of plasmid PNL42. The thermal cycler, AB Applied Biosystems Gene Amp PCR System, was performed with following condition: initial PCR activation for 15 min at $95^{\circ} \mathrm{C} ; 40$ cycles of denaturing for $30 \mathrm{sec}$ at $94^{\circ} \mathrm{C}$, annealing for $30 \mathrm{sec}$ at $56^{\circ} \mathrm{C}$, and extension for $30 \mathrm{sec}$ at $72^{\circ} \mathrm{C}$; and final extension for $10 \mathrm{~min}$ at $72^{\circ} \mathrm{C}$. The PCR products were purified by QIAquick PCR Purification Kit (Qiagen) following the manufacturer's instruction.

The PCR products were double-stranded DNA(s) with an AA-overhang at each of $5^{\prime}$ and $3^{\prime}$ ends. The AA overhangs were then blunted by using Platinum $P f x$ DNA Polymerase (Invitrogen) with following concentrations: 1x Pfx Amplification Buffer, $1.25 \mathrm{U}$ of Platinum $P f_{x}$ DNA Polymerase, $200 \mu \mathrm{M}$ of dNTP mix, $1 \mathrm{mM} \mathrm{MgSO}_{4}$, $30 \mu \mathrm{L}$ of final elution of PCR product. The mixture was consecutively incubated at $94^{\circ} \mathrm{C}$ for $4 \mathrm{~min}$ and at $68^{\circ} \mathrm{C}$ for $60 \mathrm{~min}$. The blunt-ended DNA fragments were then purified by QIAquick PCR Purification Kit (Qiagen) following the manufacturer's instruction.

For construction of the recombinant plasmid, the bluntended DNA fragments were inserted into pBluescript II KS that was previously restricted by Sma I enzyme (blunt-ended restriction). The recombinant plasmid contains sequences corresponding to nucleotide (nt) from $1 \pm 857$ to $1 \pm 967$ of the HIV-1 genome, preceded by the sequence for the bacteriophage T7 RNA polymerase promoter. To confirm the exact orientation of insert, we analyzed the orientation by PCR using M13F and HI967R primers (Figure 1).

\section{RNA transcription}

Before RNA transcription was performed, the circular recombinant plasmids were restricted by EcoRI enzyme to produce the linier DNA plasmids (Figure 1). Afterwards, those were cleaned by using QIAquick PCR Purification Kit (Qiagen), and the cleaned plasmids were used as template for RNA transcription. RNA transcription reaction was performed in $50 \mu \mathrm{L}$ of reaction mixture with following compositions: $1 \times$ T7 Reaction buffer; $1 \mathrm{mM}$ of each ATP, GTP, UTP, and
TTP; 10 mM DTT; 50 U of T7 RNA polymerases; 56 $\mathrm{U}$ of RNase Inhibitors; 1.250 ng DNA template. The mixture was incubated at $37^{\circ} \mathrm{C}$ for $60 \mathrm{~min}$ using Thermal cycler (AB Applied Biosystems Gene Amp PCR System), followed by adding $200 \mathrm{U}$ of DNase into the reactionmix and incubated at $37^{\circ} \mathrm{C}$ for $30 \mathrm{~min}$. The reaction was terminated by incubating at $85^{\circ} \mathrm{C}$ for $5 \mathrm{~min}$.

\section{Confirmation of RNA transcription}

The result of RNA transcription was used as template for RT-PCR and PCR reactions in which both reactions were conducted simultaneously. The PCR reaction was performed with composition and condition as mentioned above, while the RT-PCR was performed in $20 \mu \mathrm{L}$ of reaction mixture with following compositions: 1x One-step RT-PCR Buffer, $2.5 \mathrm{mM} \mathrm{MgCl}{ }_{2}$, 1x Q solution, $400 \mu \mathrm{M}$ of dNTP mix; 0.6 $\mu \mathrm{M}$ of each HI853F and HI967R primer; One-Step RTPCR enzyme mix (Qiagen), $4 \mu \mathrm{L}$ of RNA transcripts. The thermal cycler, AB Applied Biosystems Gene Amp PCR System, was performed with following condition: reverse transcription for $30 \mathrm{~min}$ at $50^{\circ} \mathrm{C}$; initial PCR activation for $15 \mathrm{~min}$ at $95^{\circ} \mathrm{C} ; 40$ cycles of denaturing for $30 \mathrm{sec}$ at $94^{\circ} \mathrm{C}$, annealing for $30 \mathrm{sec}$ at $56^{\circ} \mathrm{C}$, and extension for $30 \mathrm{sec}$ at $72^{\circ} \mathrm{C}$; and final extension for $7 \mathrm{~min}$ at $72^{\circ} \mathrm{C}$. The amplicons were analyzed on $8 \%$ polyacrilamide gel.

\section{Gel electrophoresis}

RNA Transcription, PCR, and RT-PCR products were analyzed on $8 \%$ polyacrylamide gel that was consisted (1 gel) of $500 \mu \mathrm{L} 10 \mathrm{x}$ TBE [0.089 M Tris base, 0.089 $\mathrm{M}$ boric acid, $0.02 \mathrm{M}$ EDTA, $\mathrm{pH}$ 8.0]; $1.350 \mu \mathrm{L}$ of $30 \%$ acrylamide; $3.150 \mu \mathrm{L}$ of distillated water; 25 $\mu \mathrm{L}$ of ammonium persulphate (APS), and $2.5 \mu \mathrm{L}$ of TEMED (N,N, N',N'-Tetramethylethylenediamine). The gels were stained with ethidium bromide after electrophoresis, and RNA or DNA bands on gels were visualized by exposing the gels on ultraviolet light.

\section{RESULTS}

\section{Recombinant plasmid}

pBluescript II SK was used for constructing the recombinant plasmid containing a 115-bp DNA of HIV-1 (Figure 1). Of the tested putative 20 recombinant plasmids, five plasmids contained the HIV-1 DNA (insert) with the exactly true orientation (data not shown). The insert orientation was confirmed by the PCR technique by using specific primers (Figure 1).

\section{RNA transcription}

Before the recombinant plasmid used as template for RNA transcription, the plasmid was restricted by EcoRI enzyme to linearize the plasmid in order T7 RNA polymerase to terminate the transcription (Figure 1). 
Mixture of RNA transcription reaction was analyzed on polyacrylamide gel and showed three bands (Figure 2A). After adding DNase enzyme into the mixture, only two bands were detected (Figure 2B). The results indicated that bands above $300 \mathrm{bp}$ and slightly above 1353-bp DNA markers were thought as RNA fragments because after adding DNase the the fragments still existed. The recombinant plasmids were detected on gel if untreated with DNase (Figure 2A, lane 1\&2), and were not detected after treated with DNase (Figure 2B, lane $1 \& 2)$; convincing that the recombinant plasmids were DNA fragments used as template for RNA transcription.

\section{Confirmation of RNA transcription}

To ensure the reaction of RNA transcription worked well, the transcription products were confirmed by one- tube RT-PCR reaction. A positive RT-PCR was defined by a $115 \mathrm{bp}$ DNA fragment visualized at the right position on polyacrylamide gel (Figure 3). To know whether RNA of transcription reaction was amplified by RT-PCR technique, PCR was performed simultaneously with RT-PCR. The confirmation assay showed that there was a 115 bp DNA fragment detected by RT-PCR on $8 \%$ polyacrylamide gel (Figure 3, line rpS), and there was no any DNA fragment/band resulted by PCR (Figure 3, line $\mathrm{pS})$. The results were supported by results of reactions for negative and positive controls showing no contamination and well working reaction, respectively (Figure 3). The data showed that we successfully transcribed RNA of a conserved region of HIV-1 Gag gene.

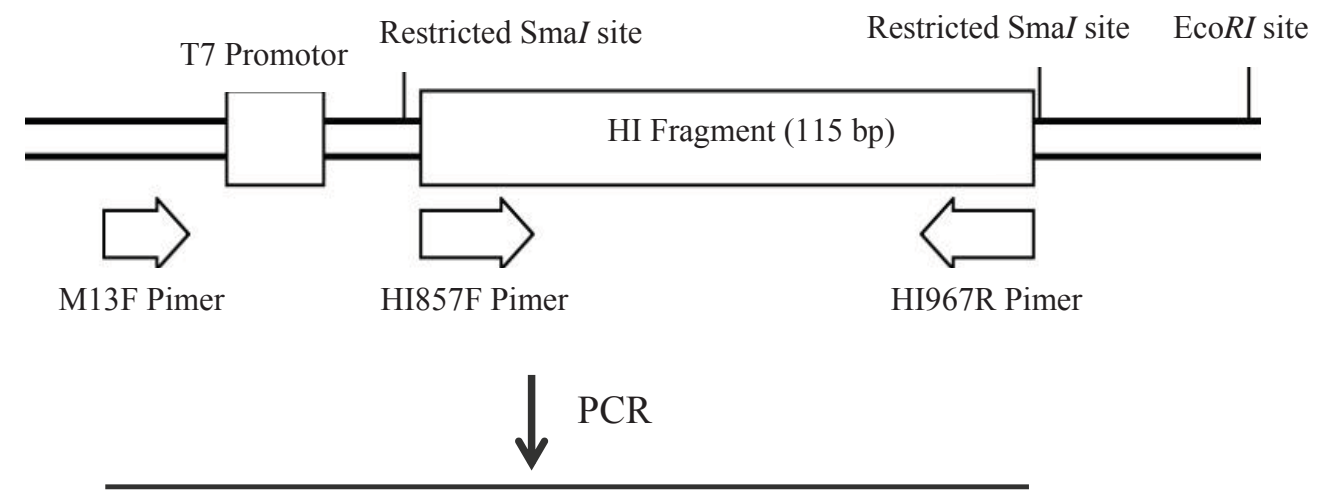

PCR Product (130 bp) if the insert is true orientation

Figure 1. Scheme of partly recombinant plasmid containing insert (HI fragment). The HI fragment was inserted in SmaI restriction site. The EcoRI enzyme was used to linearize the recombinant plasmid before used as template for RNA transcription. The aim of the restriction by EcoRI was to terminate the transcription reaction by RNA polymerase. M13F and HI967R primers were used for confirmation of the true insert orientation.

A.

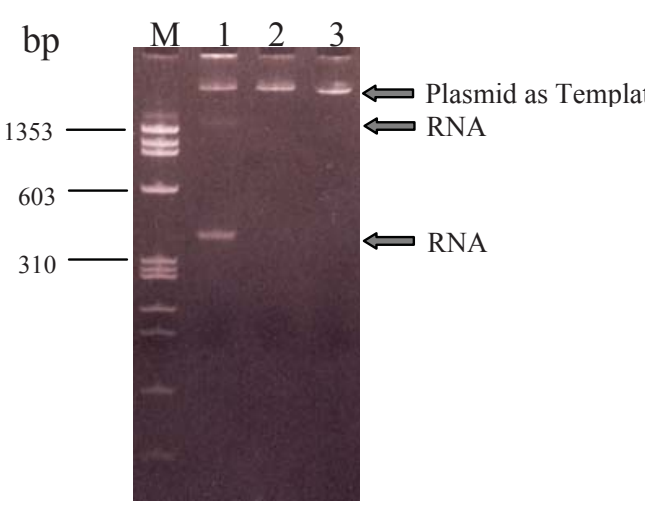

B.

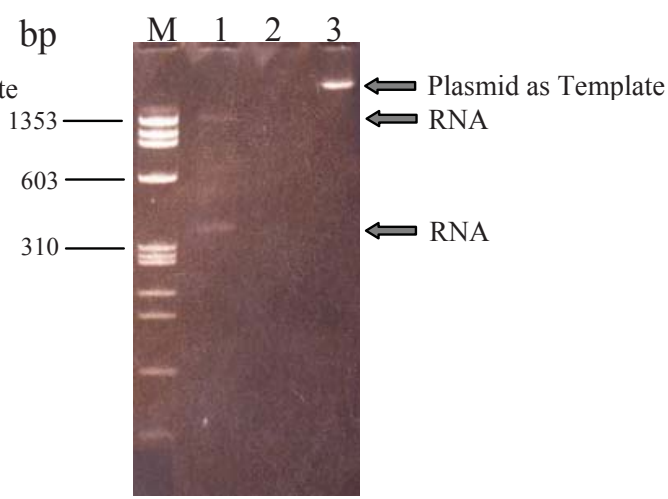

Figure 2. Analysis of RNA transcription reaction results on $8 \%$ polyacrylamide gel. A. before adding DNase enzyme. B. after adding DNase enzyme. Line M: DNA ladder. Line 1: result of RNA transcription reaction. Line 2: negative control for RNA transcription reaction. Line 3: control for plasmid used as template. bp: base pair. 


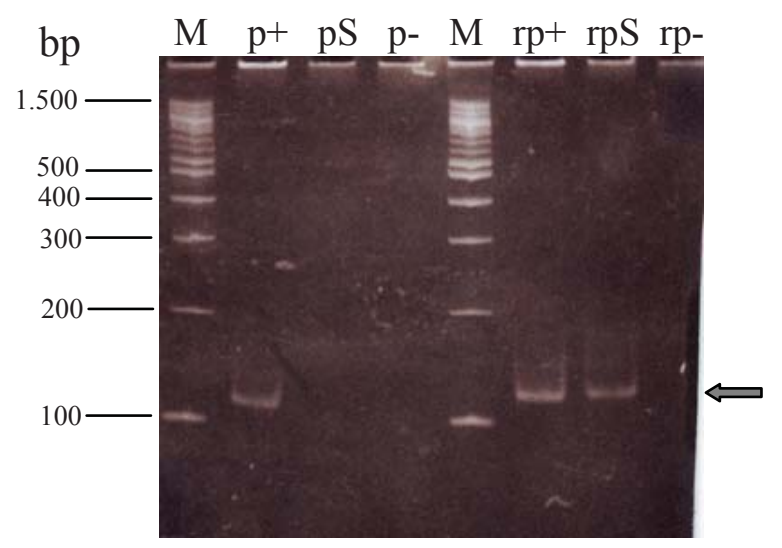

Figure 3. Confirmation of RNA transcription result by PCR and RT-PCR. Line M: DNA ladder. p: PCR. rp: RT-PCR. +: positive control. S: RNA transcription result after adding DNase enzyme. -: negative control.

\section{DISCUSSION}

Most of HIV-1 infected people take 5-10 years after initial infection to progress to acquired immunodeficiency syndrome (AIDS). ${ }^{7}$ The quantitative assays are important tests for predicting the course of HIV-1 infection and are very useful in management of patients with HIV/AIDS. ${ }^{3-5,8}$ Our objective in this study was to optimize the reaction of the HIV-1 RNA transcription to produce the standard HIV-1 RNA. The standard RNA will be very useful in development of quantitative RTPCR assay in the future.

Before performing the RNA transcription, we amplified a conserved fragment of HIV-1 Gag gene and then it inserted into pBluescript II SK. The plasmid has a bacteriophage T7 RNA polymerase promoter as a recognition site for RNA polymerase to initiate the RNA transcription. (Figure 1). Other researchers used different types of plasmids for constructing the recombinant plasmid for in vitro RNA transcription such as pET-3a, pUC19, and pAR1219 vectors. ${ }^{9-}$ ${ }^{11}$ Those the vector used in this study have the same principles as those used in other studies, which have a recognition site, in the upstream of an inserted gene, for T7 RNA polymerase to initiate RNA transcription. For terminating the RNA transcription, some researchers used a $\mathrm{T} 7$ terminator sequence in downstream of inserted gene that will give a signal for T7 RNA polymerase to stop the transcription. ${ }^{9},{ }^{12}$ In this study, we used EcoRI to linearize the plasmid in order T7 RNA polymerase to terminate the transcription (Figure 1). The same strategy was also reported by other researchers. ${ }^{10,13,14}$

Since general intention of this study is the production of HIV-1 standard RNA for quantitative assay of HIV-1 genome, we focused on the insert orientation in the recombinant plasmid. This constitutes the important step so that RNA(s) transcribed by RNA polymerase are positive-sense RNA(s) as HIV-1 has genome so. Therefore, before using the recombinant plasmid as template for RNA transcription, its inserted orientation has to be analyzed. One technique for confirmation of true orientation of inserted DNA fragment or gene is sequencing method. ${ }^{14,15}$ However, in this study we used a different approach, namely PCR technique using specific primers (Figure 1).

According to a map of recombinant plasmid illustrated in Figure 1 revealed that a 130-bp RNA fragment should be transcribed. However, as shown in Figure 2 two RNA fragments with unexpected sizes were detected. This pattern were also reported by Zlatko Legic. ${ }^{16}$ The presence of two RNA fragments with unexpected sizes is caused by type of polyacrylamide gel used, namely nondenaturing gel. Such gel is not suitable for determining accurately RNA size. The RNA can form extensive secondary structure via intra-molecular base pairing. ${ }^{17}$ The structure will occasionally give multiple bands that are probably caused by the single-stranded RNA forming a number of different structural conformations. ${ }^{18}$ In addition, topology of RNA can also affect its migration, making RNA to appear longer on the gel. ${ }^{19}$ One reason why we used non-denaturing gel to analyze singlestranded RNA was to determine the integrity of the RNA transcript. As showed in Figure 2 that the RNA transcript has good integrity that indicates the correct procedure of RNA transcription reaction without RNA degradation and the ready step to further application.

The RT-PCR and PCR assays were performed simultaneously for confirmation of RNA transcription (Figure 3), as also conducted by other researchers., ${ }^{9} 20,21$ By the strategy, the RT-PCR products and no PCR product will be detected if RNA is transcribed successfully. The RT-PCR product is DNA fragment resulted from RT enzyme activity from RNA into cDNAs, and those are then amplified by DNA polymerases to synthesize double-stranded DNA. Figure 3 showed that a 115-bp was detected by RT-PCR but not by PCR, indicating that the HIV-1 RNA has been successfully transcribed.

In conclusion, we successfully constructed the recombinant plasmid containing the conserved region of the HIV-1 Gag gene with true orientation for in vitro RNA transcription reaction. The HIV-1 RNA has also successfully been transcribed. In the future, the RNA will be used as standard RNA in a quantitative RT-PCR assay.

\section{Acknowledgments}

This research was funded by Riset Unggulan Universitas Indonesia (RUUI) tahun 2005. 


\section{REFERENCES}

1. Mylonakis E, Paliou M, Lally M, Flanigan TP, Rich JD. Laboratory testing for infection with the human immunodeficiency virus: established and novel approaches. Am J Med. 2000;109:568-76.

2. Yasmon A, Fatmawati NND, Ibrahim F, Bela B. A second generation of RT-PCR assay for detection of human immunodeficiency virus type 1 (HIV-1) infection. Med J Indones. 2010;19:154-7.

3. Fiscus SA, Cheng B, Crowe SM, Demeter L, Jennings $\mathrm{C}$, Miller V, et al. HIV-1 viral load assays for resourcelimited settings. PLoS Med. 2006;3:e417.

4. Mylonakis E, Paliou M, Rich JD. Plasma viral load testing in the management of HIV infection. Am Fam Physician. 2001;63:483-90.

5. Kamara P, Melendez-Guerrero L, Arroyo M, Weiss H, Jolly P. Maternal plasma viral load and neutralizing/ enhancing antibodies in vertical transmission of HIV: a non-randomized prospective study. Virol J. 2005;2:15.

6. Ausubel FM, Brent R, Kingston RE, Moore DD, Seidman JG, Smith JA, et al., editors. Current protocols in molecular biology. Vol:1. New York, Greene Publishing Associates and Wiley-Interscience, 990.

7. Silva Mde O, Bastos M, Netto EM, Gouvea NA, Torres AJ, Kallas E, et al. Acute HIV infection with rapid progression to AIDS. Braz J Infect Dis. 2010;14:291-3.

8. Berger A, Preiser W. Viral genome quantification as a tool for improving patient management: the example of HIV, HBV, HCV and CMV. J Antimicrob Chemother. 2002;49:713-21.

9. Steffen J, von Nickisch-Rosenegk M, Bier FF. In vitro transcription of a whole gene on a surface-coupled template. Lab Chip. 2005;5:665-8.

10. Pleiss JA, Derrick ML, Uhlenbeck OC. T7RNA polymerase produces 5' end heterogeneity during in vitro transcription from certain templates. RNA. 1998;4:1313-7.
11. Guillerez J, Lopez PJ, Proux F, Launay H, Dreyfus M. A mutation in T7 RNA polymerase that facilitates promoter clearance. Proc Natl Acad Sci USA. 2005;102:5958-63.

12. Sathyanarayana UG, Freeman LA, Lee MS, Garrard WT. RNA polymerase-specific nucleosome disruption by transcription in vivo. J Biol Chem. 1999;274:16431-6.

13. Chang J, Taylor J. In vivo RNA-directed transcription, with template switching, by a mammalian RNA polymerase. EMBO J. 2002;21:157-64.

14. Gurukumar KR, Priyadarshini D, Patil JA, Bhagat A, Singh A, Shah PS, et al. Development of real time PCR for detection and quantitation of Dengue Viruses. Virol J. 2009;6:10.

15. Glynn B, Lacey K, Reilly J, Barry T, Smith TJ, Maher M. Quantification of bacterial tmRNA using in vitro transcribed RNA standards and two-step qRT-PCR. Res J Biol Sci. 2007;2 (5):564-70.

16. Lejic Z. Exploring Methods for the characterization of viral RNA-protein complexes [thesis]. Canada University of Waterloo; 2009.

17. Todorov TI, de Carmejane O, Walter NG, Morris MD. Capillary electrophoresis of RNA in dilute and semidilute polymer solutions. Electrophoresis. 2001;22:2442-7.

18. Clarke PA. Labeling and purification of RNA synthesized by in vitro transcription. In: Haynes SR. Methods in molecular biology. RNA-protein interaction protocols. Totowa, Humana Press Inc; 1999.

19. Rio DC, Ares M, Jr., Hannon GJ, Nilsen TW. Nondenaturing agarose gel electrophoresis of RNA. Cold Spring Harb Protoc. 2010:pdb prot5445.

20. Kleiboeker SB. Applications of competitor RNA in diagnostic reverse transcription-PCR. J Clin Microbiol. 2003;41:2055-61.

21. Kudla G, Lipinski L, Caffin F, Helwak A, Zylicz M. High guanine and cytosine content increases mRNA levels in mammalian cells. PLoS Biol. 2006;4:e180. 